\title{
Adapting CEAB Graduate Attributes to Promote Graduate Student Success in the Canadian Engineering Community
}

\author{
Susan Caines ${ }^{1}$ and Leonard M. Lye $e^{2}$ \\ ${ }^{1}$ Memorial University, Marine Institute, School of Ocean Technology \\ ${ }^{2}$ Memorial University, Faculty of Engineering and Applied Science \\ Susan.Caines@mi.mun.ca
}

\begin{abstract}
Graduate engineering programs at Memorial University's Faculty of Engineering and Applied Science are not accredited and as such there is no information available on non-technical professional skills development. These skills are essential for successful entry into the Canadian engineering community. To assess the current graduate program, an assessment methodology was developed based on the CEAB graduate attribute assessment process used for undergraduate program accreditation. An initial application of this methodology to Process Engineering indicates that all professional skills are not covered for all students. This lead to modifications for current programing that will ensure all students are exposed to the skills needed for a successful career in engineering.
\end{abstract}

Keywords: Graduate program design: Professional skills assessment: Graduate attributes: Community integration.

\section{INTRODUCTION}

All undergraduate engineering programs in Canada are accredited by the Canadian Engineering Accreditation Board (CEAB). This board assesses all university undergraduate engineering programs to ensure each graduating engineer satisfies the academic requirements for licensing as a professional engineer in each province and territory. Engineers Canada developed a list of attributes that all graduates of Canadian undergraduate engineering programs will satisfy. These include both technical and professional skills and ensure that undergraduate engineering students will satisfy the expectations of industry and that they will have the skills needed to quickly become contributing members of the engineering community.

Unlike undergraduate engineering programs, graduate engineering programs, both Masters and Doctorate levels, in Canada are not accredited and as such each university may develop programs as they wish to prepare graduate engineering students for a future in the engineering community. There are universities in Canada that are required to review their program, for example Ontario University programs are approved by the Ontario Council on Graduate Studies (OCGS) through external reviews. While this process ensures quality programming it does not assess graduate programs against any specific criteria such as the 12 graduate attributes employed by the CEAB to accredit undergraduate engineering programs in Canada. Currently, MUN does not have a mandated graduate review program however there is an internal review process (Academic Program Review (APR)) that is conducted every 7 years. This review process uses selfstudy and external reviewers to evaluate a programs academic planning, opportunity identification, and to evaluate the quality and success of each academic program [1]. While this is a successful review process it does not specifically review graduate student learning outcomes or skill development.

Some universities in the United States use an internal assessment process to assess their graduate program. At the University of Rhode Island [3] there is a graduate program assessment plan required for each program. This assessment includes overall program goals, student learning goals linked to curriculum and an assessment timeline to demonstrate when and where learning assessment occurs. The assessment plan is then assessed by an internal reviewer using a specific set of criteria. The University of Minnesota (U of M) [5] developed tools to identify and communicate specific graduate program goals and methods for student assessment to these goals. U of $\mathrm{M}$ held workshops to introduce faculties to the process. The Aerospace Engineering and Mechanics Program [2] followed the process and through consultation with faculty and students the identified 4 high level graduate learning outcomes:

1. Knowledge and scholarship

2. Intellectual curiosity

3. Communication skills

4. Ability to work in a group/team 
These outcomes are assessed through coursework, research productivity (journal and conference papers) and through mandatory examinations.

At Memorial University's Faculty of Engineering and Applied Science (FEAS) a large portion of graduate students do not graduate from Canadian undergraduate engineering programs and are not always assessed for all the skills required by $\mathrm{CEAB}$ in their undergraduate program. Graduate students come from a variety of countries and have diverse experience that they bring to the community. These experiences and education may not fully prepare them for a future in Canadian engineering environments. To facilitate student success in Canada, MUNs FEAS has begun informally assessing its current graduate programs in terms of the graduate attributes set out by the CEAB. The review of graduate engineering program focusses on non-traditional skills including graduate attributes 6-12. The traditional skills demonstrated in graduate attributes 1-5 are well covered through course and research work required for graduation. The first stage of this assessment concentrated on the graduate attributes that contribute to professional skills including communication skills, professionalism, impact of engineering on society and the environment, and ethics and equity, economics and project management, and lifelong learning. One of the key attributes that the initial assessment found to be lacking in MUNs graduate program was ethics education. This gap was partially addressed through a mandatory seminar course that introduced ethical decision making strategies to all students [4].

A second assessment of the graduate engineering program is planned at Memorial University. This more formal assessment will use some of the tools designed for undergraduate engineering program accreditation to evaluate the graduate engineering program according CEAB graduate attributes 6-12. This paper outlines the methods planed the results of an assessment on a Process Engineering Master's program. Potential modifications to the assessment process and the program are outlined.

\section{ASSESSMENT METHODOLOGY}

The assessment of the graduate program focuses on the professional skills outlined by the CEAB including graduate attributes:

6. Individual and Teamwork

7. Communication skills

8. Professionalism

9. Impact of Engineering on Society and the Environment

10. Ethics and Equity

11. Economics and Project Management

12. Lifelong Learning

\subsection{Methodology Development}

Memorials FEAS graduate programs include Graduate diplomas, course based Master of Applied Science (MASc), thesis based Master of Engineering (MEng) and $\mathrm{PhD}$ programs. The research based MEng program includes a balance of both course work and research activities in engineering and as such the initial assessment is limited to thesis based MEng students. This assessment will lay the groundwork for future assessments of more course intensive programs (Graduate diplomas and $\mathrm{MASc})$ and more research intensive programs $(\mathrm{PhD})$.

Unlike undergraduate engineering programs, graduate engineering programs do not follow a common curriculum. For thesis based programs, students must complete 6 of their 12 credit hours in pre-determined core courses. There are 35 core courses for students to choose from. The variety of courses offered and the diversity of research topic lead to many possible programs of study for graduate students. ENGI9100, Graduate Seminar is the only common course required by thesis based graduate students.

\subsection{Methodology}

The following process was adapted from the FEAS undergraduate accreditation and continuous improvement process and proposed for graduate program assessment.

1. Examine course learning outcomes to identify connection to graduate attributes 6-12.

2. Develop curriculum maps to determine competency levels for each course in terms of graduate attributes 6-12.

3. Review individual student programs to determine probability of attribute attainment.

4. Develop thresholds for program acceptance.

\section{RESULTS AND DISCUSSION}

The assessment methodology is planned for seven Masters level research programs including Civil, Mechanical, Electrical, Computer, Ocean and Naval Architecture, Process, and Oil \& Gas. Process engineering graduate program was chosen as a test case for the assessment process.

\subsection{Results to date}

Common learning outcome course outlines are not available for all graduate program courses. To complete step one of the assessment methodology, discussions with course instructors are needed to consolidate and in cases develop learning outcomes for all courses offered. 
Learning outcomes were identified for some graduate courses.

Table 1 illustrates the curriculum map for graduate attributes for process engineering specific graduate courses.

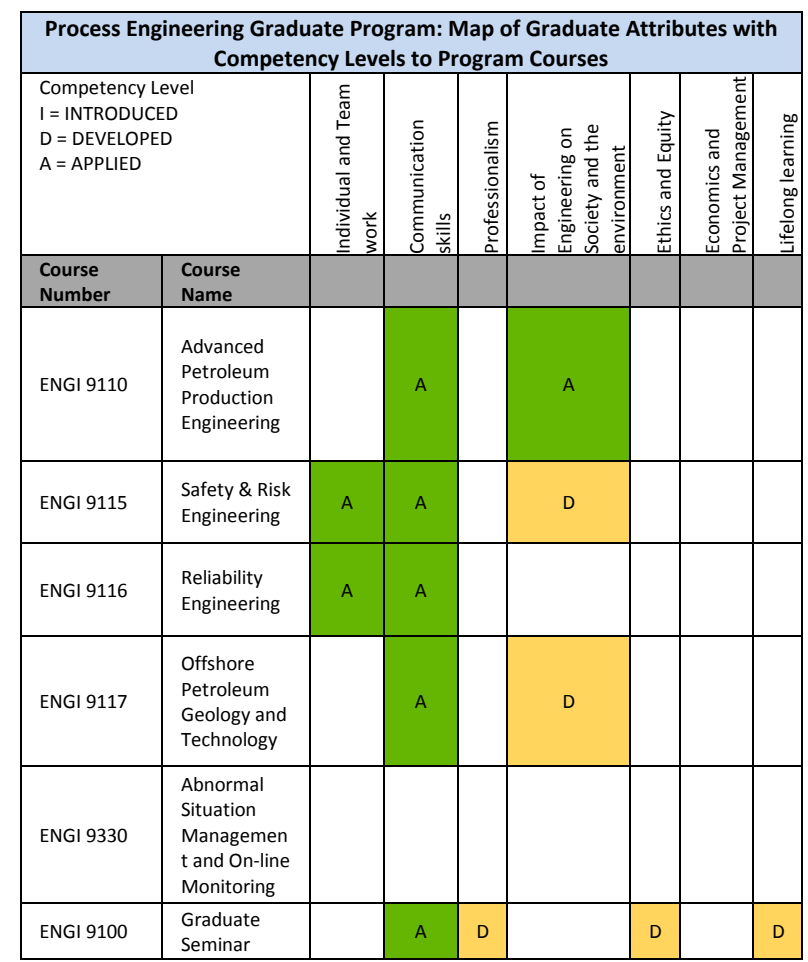

To complete step 3 of the methodology past and current process engineering student programs of study will be collected and analyzed to determine current attribute attainment. From this information, discussions with department heads and the associate dean of graduate studies will determine the acceptance level for future graduate students (step 4).

Table 1: Estimated competency level curriculum map for process engineering.

\subsection{Discussion}

Based on the initial review it is clear that there are gaps and blanks in the current graduate program that must be addressed to ensure graduate students develop all the skills required for successful integration into the Canadian engineering community.

The main issues with implementing significant changes that will affect all graduate students is that each student has an individual program that is tailored to their program of study and research. With only one common course for thesis based MEng students, this is the first place to endeavor to include additional.
3.2.1 Modification to ENGI 9100. The graduate seminar is a one credit mandatory course traditionally focused on communication skills and was a general introduction to graduate studies at MUN. Over time, this program has grown to include research and lifelong learning skills presented by the schools librarian, ethical decision making, avoiding plagiarism and an introduction to engineering professionalism. It is proposed that sessions are added to include lectures and discussion on the global impact of engineering on society and increase the course content to expand the development of professionalism. To include these topics and increase the engagement of students, it is suggested that this course is developed into a 2 or 3 credit hour course.

3.2.2 Addition of thesis writing course. Discussions with faculty indicate the need for additional skill development in writing for MEng students. A proposal to add a writing course specifically to address technical writing is recommended. This course would improve the communication skills of students and well prepare them for their thesis development, research planning and future publications.

3.2.3 Development of a program assessment form. To ensure all graduate attributes are well covered and integrated into each MEng students program of study, a new program of study assessment form is recommended.

This assessment form would be required for all students in addition to the current program of study form currently used to declare courses. These forms will be completed by the student in consultation with their supervisor(s) and will ensure that the planed program of study includes courses and activities that address the professional skills needed for success in engineering communities. Specific research activities must be eligible to satisfy the graduate attributes and included on the assessment form.

A complete competency level map for all graduate courses will be required for students as a reference to determine the inclusion and level of professional skill development in their chosen course.

This form will ensure conscious inclusion of nontraditional engineering skills in students study and increase the level of engagement in active learning planning.

The form will follow the format of the "Graduate Program Student Learning Outcomes Assessment Plan

For Accredited and Non-Accredited Programs"[3] developed by The University of Rhode Island. The form will include general program information and overall goals. The form will also include a curriculum map that demonstrates how the chosen program of study including research activities satisfies the graduate attribute 
requirement. A demonstration of potential format for this section is shown in Table 2.

3.2.3 Potential issues. To complete the above modifications faculty co-operation is required. Individual

\begin{tabular}{|c|c|c|c|c|c|c|c|c|}
\hline \multicolumn{2}{|c|}{$\begin{array}{l}\text { Competency Level } \\
\text { I = INTRODUCED } \\
D=\text { DEVELOPED } \\
A=\text { APPLIED }\end{array}$} & 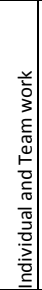 & 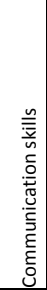 & 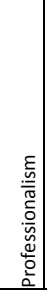 & 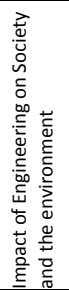 & 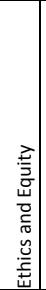 & 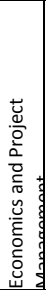 & 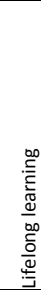 \\
\hline $\begin{array}{l}\text { Course } \\
\text { Number }\end{array}$ & Course Name & & & & & & & \\
\hline $\begin{array}{l}\text { ENGI } \\
9110\end{array}$ & $\begin{array}{l}\text { Advanced } \\
\text { Petroleum } \\
\text { Production } \\
\text { Engineering }\end{array}$ & & A & & A & & & \\
\hline $\begin{array}{l}\text { ENGI } \\
9115\end{array}$ & $\begin{array}{l}\text { Safety \& Risk } \\
\text { Engineering }\end{array}$ & A & A & & $\mathrm{D}$ & & & \\
\hline $\begin{array}{l}\text { ENGI } \\
9116 \\
\end{array}$ & $\begin{array}{l}\text { Reliability } \\
\text { Engineering }\end{array}$ & A & A & & & & & \\
\hline $\begin{array}{l}\text { ENGI } \\
9117\end{array}$ & $\begin{array}{l}\text { Offshore } \\
\text { Petroleum } \\
\text { Geology and } \\
\text { Technology }\end{array}$ & & & & D & & & \\
\hline $\begin{array}{l}\text { ENGI } \\
9100\end{array}$ & $\begin{array}{l}\text { Graduate } \\
\text { Seminar }\end{array}$ & & A & D & & D & & $D$ \\
\hline Research & $\begin{array}{l}\text { Research } \\
\text { Project } \\
\text { Management }\end{array}$ & & & & & & A & \\
\hline Research & $\begin{array}{l}\text { Literature } \\
\text { review }\end{array}$ & & & & & & & A \\
\hline Research & Publication & & A & & & & & \\
\hline Research & $\begin{array}{l}\text { Conference } \\
\text { Presentation }\end{array}$ & & A & & & & & A \\
\hline Research & $\begin{array}{l}\text { Lifecycle } \\
\text { Assessment }\end{array}$ & & & & A & & & \\
\hline Research & Impact Study & & & & $\mathrm{A}$ & & & \\
\hline Research & Ethics Review & & & & $A$ & A & & \\
\hline
\end{tabular}

faculty members are responsible for the content of their course and not all employ outcome based planning for their courses. While all faculty are actively engaged in learning outcome development for their undergraduate courses, some faculty may resist the assessment process on their graduate courses.

Table 2: Estimated competency level curriculum map for process engineering.

\section{CONCLUSIONS}

This work outlines the proposed plan for complete assessment of the graduate engineering program at MUN using a modified version of the CEAB accreditation process for MUN undergraduate engineering programs. Process engineering was chosen as a test case and an initial assessment of courses indicates that there are significant gaps in formal education covering the 7 identified graduate attributes. It is suggested that modifications be made to the graduate program requirements to ensure all students are exposed to these professional skills needed for future success. These modifications include:

1. Modification to the graduate seminar course.

2. Addition of a writing course.

3. Development of a program assessment form.

To ensure successful implementation of these modifications, all courses available to graduate students must be evaluated in terms of the identified attributes and the assessment process completed.

\section{References}

[1] Academic Program Review of the Faculty of Engineering \& Applied Science, Memorial University of Newfoundland and Labrador, Retrieved May 2017 from https://www.mun.ca/vpacademic/APR/ENGI 2014 PanelRe port.pdf

[2] Aerospace Engineering and Mechanics Graduate Learning Goals and Outcomes, University of Minnesota,, Graduate Program Goals, Retrieved April 2017 from http://grad2.umn.edu/goals/assets/aem.pdf

[3] Graduate program assessment planning, University of Rhode Island, (April 2017) Retrieved from http://web.uri.edu/assessment/g_planning_forms/

[4] Susan Caines and Leonard Lye, "Enhancing Learning Experiences of Graduate Students in the Faculty of Engineering and Applied Sciences at Memorial University of Newfoundland," in Proc. CEEA Canadian Engineering Education Conf., CEEC 2015, (McMaster University May31-June 3, 2015)

[5] University of Minnesota,, Graduate Program Goals, (April 2014) Retrieved from http://grad2.umn.edu/goals/assets/report.pdf 